\author{
Monika Scheidler* \\ ORCID: 0000-0003-4722-5541 \\ Drezno, Niemcy
}

\title{
Aspekty pedagogiczne w duchowości jedności wynikającej z mistycznego doświadczenia Chiary Lubich
}

\author{
Fundamental Aspects of Education \\ in the Light of the Spirituality of Unity - \\ considering the Mystical Experience \\ of Chiara Lubich
}

\begin{abstract}
Summary: This contribution identifies and exemplifies the specific resources of inspiration and motivation that educators who live the spirituality of unity can exploit for their commitments in the field of education; that is, to create pedagogical relational spaces in particular.
\end{abstract}

Keywords: educational anthropology; theological anthropology; educational relations; trinitarian relations; mystical experience of Chiara Lubich.

* Monika Scheidler, profesor pedagogiki religii, katechetyki i teologii pastoralnej na Wydziale Teologii Katolickiej Uniwersytetu Drezdeńskiego w Niemczech. Adres: Technische Universität Dresden, Institut für Katholische Theologie, 01062 Dresden, Germany; e-mail: Monika.Scheidler@tu-dresden.de. 
Streszczenie: W artykule ukazano konkretne źródła inspiracji i motywacji, które wychowawcy żyjący duchowością jedności Ruchu Focolari, założonego przez Chiarę Lubich, mogą wykorzystywać w swoich działaniach w dziedzinie wychowania, zwłaszcza w kreowaniu pedagogicznych przestrzeni relacyjnych.

Slowa kluczowe: antropologia edukacyjna; antropologia teologiczna; relacja wychowawcza; relacje trynitarne; mistyczne doświadczenie Chiary Lubich.

Dorośli - odpowiedzialni za edukację i wychowanie w przedszkolach, szkołach, na uniwersytetach czy też w środowiskach pozaszkolnych, w rodzinach albo we wspólnotach religijnych itp. - mają za zadanie przekazywać podstawy kultury i wiedzy oraz promować edukację społeczną, co przyczynia się do rozwoju umiejętności samostanowienia, współzarządzania, a także solidarności ${ }^{1}$.

$\mathrm{Na}$ poziomie praktyki edukacyjnej ważne jest tworzenie przestrzeni, w których można doświadczać otwartości, ufności i wolności w relacjach pełnych/naznaczonych dowartościowaniem drugiego i szacunkiem. Takie przestrzenie rodzą się w środowisku pracy otwartym i wolnym od uprzedzeń oraz egoistycznych nastawień. To w nich, dzięki słuchaniu i świadomej aktywności drugiego, staje się możliwe całościowe zrozumienie siebie. Miejsca te stymulują empatyczne działanie, uzdalniające do wychodzenia poza siebie, oraz wzajemne zrozumienie. Warunkiem koniecznym do tworzenia relacyjnych przestrzeni jest ufność wychowawcy lub zdolność do otwartego spojrzenia na swoje życie. W takiej przestrzeni pomiędzy nauczycielami a uczniami, rodzicami a dziećmi, wychowawcami a rodzicami może zaistnieć pewnego rodzaju wspólnotowe uczenie się, które sięga znacznie dalej niż tylko przekazywanie wiedzy, a ponadto uwydatnia kompetencje osobiste i społeczne. Tworzenie przestrzeni relacyjnych, ukierunkowanych na wzajemne zrozumienie, jest cechą niezbędną wszelkiej praktyki edukacyjnej.

${ }^{1}$ Por. Wolfgang Klafki, „Zur Unterrichtsplanung im Sinne kritisch-konstruktiver Didaktik", w: Neue Studien zur Bildungstheorie und Didaktik. Zeitgemäße Allgemeinbildung und kritisch-konstruktive Didaktik, red. Wolfgang Klafki (Weinheim und Basel: Beltz Verlag, 1996), 251-284, 256. 
Problematykę podjętą w tym artykule można wyrazić kluczowym pojęciem ${ }^{2}$ pedagogii relacji ${ }^{3}$. Zostało ono przyjęte przez pedagogów pochodzących z krajów języka niemieckiego dla określenia prac prowadzonych nad pedagogią, która ma swoje korzenie w duchowości jedności ${ }^{4}$. Pojęcie to jest szerokie, $\mathrm{z}$ jednej strony bowiem odnosi się do relacji horyzontalnych z innymi (dzieci - wychowawcy; studenci - wykładowcy; nauczyciel - dyrektor szkoły) - a zatem dotyczy kompetencji nauk humanistycznych; natomiast z drugiej (dla osób otwartych na duchowy wymiar życia ludzkiego) odnosi się do relacji wertykalnych, jakie zachodzą pomiędzy Bogiem a człowiekiem, a więc sięga do kompetencji teologii, w szczególności teologii praktycznej. Każde działanie pedagogiczne wzbudza potrzebę tworzenia przestrzeni relacyjnych. Wysiłki pedagogii relacji są skoncentrowane przede wszystkim na kształtowaniu relacji wychowawczej. W refleksji nad wzajemnym odniesieniem praktyki i teorii dąży się do zweryfikowania, czy działanie pedagogiczne poszczególnych podmiotów efektywnie przyczynia się do rozwoju instytucji wychowawczych (tak aby były one głęboko ludzkie) oraz do rozwoju społeczeństwa w duchu sprawiedliwości i pokoju.

Celem tego artykułu jest wydobycie i zilustrowanie potencjału inspiracyjnego i motywacyjnego, który nauczyciele żyjący duchowością Ruchu

2 Termin ten rozumie się w znaczeniu nadanym przez Friedricha W. Krohna [por. Friedrich W. Kron, Grundwissen Didaktik (München: Reinhardt, 2000), 102-193; Friedrich W. Kron, Wissenschaftstheorie für Pädagogen (München: Reinhardt 1999), 43nn; Norbert Mette, Hermann Steinkamp, Sozialwissenschaften und Praktische Theologie (Düsseldorf: Patmos,1983), 164-176].

3 Artykuł jest rezultatem dziesięcioletniej pracy naukowców zrzeszonych w zespole, który nazywa się Pedagogia Relacji. Są to wychowawcy i nauczyciele (z krajów języka niemieckiego), którzy inspirację i motywację do swojej pracy zawodowej (w szkołach, na uniwersytetach, $\mathrm{w}$ instytucjach edukacyjnych oraz w edukacji pozaszkolnej) znajdują w duchowości Ruchu Focolari. Od 2009 r. poddano analizie główne fragmenty pism założycielki Ruchu, Chiary Lubich - opisała w nich swoje mistyczne doświadczenie z 1949 r. Zespół przeanalizował trzy kluczowe teksty: „Pakt”, „Patrzeć na wszystkie kwiaty” i „Zmartwychwstanie Rzymu”. Poszukiwano w nich wskazań dla działań edukacyjnych. Krok po kroku, dzięki wyodrębnieniu (z tych trzech wybranych tekstów) znaczących dla pedagogiki fraz i kluczowych kategorii, opracowano pierwsze interpretacje. Podczas spotkania w styczniu 2015 r. zespół opracował analizę porównawczą tych tekstów. Ponieważ w gronie Pedagogia Relacji są osoby, które oprócz nauk o edukacji specjalizują się także w teologii chrześcijańskiej (w wyznaniu katolickim), analizy i interpretacje tekstów mistycznych Lubich zostały opracowane z perspektywy nie tylko nauk o edukacji, ale także z perspektywy teologicznej - w szczególności teologii praktycznej.

${ }^{4}$ Por. Chiara Lubich, Duchowość jedności nowa droga (Kraków: Fundacja Mariapoli, 2004). 
Focolari mogą wykorzystać w swojej pracy do tworzenia pedagogicznych przestrzeni relacyjnych. W części pierwszej omówię antropologiczne podstawy pedagogicznych przestrzeni relacyjnych, stosując podwójną perspektywę: nauk o edukacji oraz teologii chrześcijańskiej. Pozwoli to na podwójny wymiar analizy tekstów Chiary Lubich o doświadczeniu mistycznym. Następnie wyszczególnione zostaną zasadnicze aspekty pedagogii inspirującej się zasadami Ruchu Focolari - na postawie wyników analizy trzech kluczowych tekstów Lubich: „Pakt”, „Patrząc na wszystkie kwiaty”6 oraz „Zmartwychwstanie Rzymu”. We wnioskach skupię się na głównych przesłankach pedagogii, która inspiruje się doświadczeniem mistycznym Lubich. $\mathrm{Z}$ jednej strony wyjaśnię konsekwencje dla dalszych prac nad podstawowymi założeniami pedagogii - zainspirowanej duchowością jedności - nie tylko w zakresie teoretycznym, ale także w odniesieniu do konkretnych projektów Ruchu Focolari w dziedzinie edukacji. Z drugiej strony przedstawię możliwości ewentualnego dialogu tej pedagogii z teorią i praktyką innych prądów pedagogicznych oraz ich projektami edukacyjnymi.

\section{Antropologiczne podstawy pedagogicznych przestrzeni relacyjnych}

Fundamentem pedagogii, której celem jest tworzenie przestrzeni relacyjnych sprzyjających rozwojowi i nauce, jest koncepcja człowieka jako wolnego podmiotu; człowieka, który ma w sobie podstawową zdolność do pozytywnego rozwoju i przekształcania swojego środowiska, czyniąc je przyjaznym życiu. W takiej perspektywie zadaniem wychowawcy jest towarzyszenie i odpowiednie wspieranie dzieci i młodzieży w ich swobodnym rozwoju ${ }^{8}$.

5 Włoskie wydanie: Chiara Lubich, "Il Patto", w: Il Patto del '49 nell'esperienza di Chiara Lubich. Percorsi interdisciplinari, red. Vera Araújo, Maria Caterina Atzori i in. (Roma: Città Nuova, 2012), 16-18.

${ }^{6}$ Polskie wydanie: Chiara Lubich, „Patrzeć na wszystkie kwiaty”, w: Chiara Lubich, Charyzmat jedności, red. Michel Vandeleene (Kraków: Fundacja Mariapoli, Wydawnictwo M, 2007), 60-62. Włoskie wydanie opublikowano w: Nuova Umanità 104 (1996): 133-135.

7 Chiara Lubich, „Zmartwychwstanie Rzymu”, w: Chiara Lubich, Charyzmat jedności, red. Michel Vandeleene (Kraków: Fundacja Mariapoli, Wydawnictwo M, 2007), 241-245. Włoskie wydanie opublikowano w: Nuova Umanità 102 (1995/6): 5-8.

${ }^{8}$ Wychodzimy więc nie z koncepcji człowieka (dziecka, młodego człowieka) rozumiejącej go jako przedmiot, który wychowawca musi prowadzić, lub wręcz nim zawładnąć [por. 
Pedagogiczną koncepcję człowieka jako wolnego podmiotu, który może się pozytywnie rozwijać i kształtować środowisko sprzyjające życiu, można połączyć z biblijną koncepcją człowieka stworzonego na obraz i podobieństwo Boga. Ta wizja antropologii teologicznej niesie ze sobą konsekwencje społeczne i etyczne ${ }^{9}$. Chodzi tu przede wszystkim o obraz Boga Trójcy (Ojca - Syna - Ducha Świętego) oraz połączoną z nim koncepcję człowieka jako obrazu Boga Trójjedynego ${ }^{10}$, który w sobie samym jest relacją, a poprzez swoje Wcielenie w Jezusie ofiarował i ciągle ofiaruje wejście w tę relację także ludziom. Rozumienie człowieka według teologii chrześcijańskiej niesie ze sobą konsekwencje etyczne nie tylko w sytuacjach pedagogicznych. Ta specyficzna inspiracja, która w świetle antropologii teologicznej pozwala bardziej zrozumieć człowieka, w duszy wychowawcy chrześcijańskiego umożliwia refleksję oraz wyciągnięcie pedagogicznych wniosków, opartych także na teologii. Co więcej, mogą być one wsparciem dla praktyki pedagogicznej, stanowiąc źródło motywacji i ukierunkowania do dalszego działania.

Patrzenie na różne sytuacje wynikające z praktyki pedagogicznej oraz interpretacja relacji wychowawczych z perspektywy tradycji biblijno-chrześcijańskiej - przede wszystkim z punktu widzenia Boga Trójjedynego - ukazują istotny potencjał nadziei i zaufania. Taki sposób postrzegania rzeczy i relacji daje także początek nowym przemyśleniom. Otwartość przyczy-

Reinhold Boschki i in. „Grundoptionen der Religionspädagogik”, w: Religionspädagogische Grundoptionen: Elemente einer gelingenden Glaubenskommunikation, red. Reinhold Boschki, i in. (Freiburg: Herder, 2008), 19-43; por. z perspektywy duchowości chrześcijańskiej: Lubich, „Zmartwychwstanie”, 251-255].

9 Także myśliciele (jak Marcin Buber), psychologowie, wychowawcy i nauczyciele żydowscy podzielają takie rozumienie. W koncepcji człowieka jako obrazu i odbicia Boga zakorzenione są nie tylko przeświadczenie o niezbywalnej godności każdego człowieka jakiegokolwiek pochodzenia i koloru skóry - ale także prawa człowieka - nawet jeśli obecne uzasadnienia praw człowieka prawie nie biorą tego pod uwagę. Koncepcja biblijna człowieka jako obrazu Boga oznacza etyczną konsekwencję szacunku wobec każdej osoby (każdego dziecka), ponieważ jest obrazem Boga. W postępowaniu etycznym oznacza to, że dostrzega się wysoką wartość każdego gestu skierowanego z miłością ku drugiemu człowiekowi. Miłość do człowieka (miłość bliźniego) rozumie się jako wyraz miłości do Boga. Na przykład miłość podarowana dziecku może być rozumiana jako znak miłości Boga do tego dziecka.

${ }^{10}$ Ta koncepcja jest podzielana także przez naukowców edukacji i nauczycieli chrześcijańskich wyznania prawosławnego [por. Athanassios Stogianidis, Leben und Denken: Bildungstheorien zwischen Theosis und Rechtfertigung. Eine Untersuchung zum Verhältnis von Evangelischer und Orthodoxer Religionspädagogik (Münster: Lit, 2003), 27-54, 113-189; Ulf Liedke, „Inklusion in theologischer Perspektive”, w: Handbuch Inklusion in der Kirchengemeinde, red. Ralph Kunz (Göttingen: Vandenhoeck \& Ruprecht, 2013), 31-52, przede wszystkim 33-35]. 
nia się do specyficznego ukierunkowania praktyki pedagogicznej i stwarza przesłanki do krytycznej oceny aktualnej rzeczywistości pedagogicznej oraz stopniowego przemieniania jej - jeśli to konieczne - w kierunku obiecującej perspektywy „różnorodności w jedności” i ,jedności w różnorodności”, połączonej z koncepcją Boga, który jest różnorodnością i relacyjnością: jest Ojcem, Synem i Duchem Świętym.

\section{Podstawowe aspekty pedagogii wynikającej z duchowości jedności}

Koncepcja człowieka jako obrazu Boga Trójjedynego leży także u podstaw inspiracji i motywacji pedagogii relacji, osadzonej na duchowości Ruchu Focolari, a ściślej na doświadczeniu mistycznym Chiary Lubich i Ruchu z 1949 r. W jego centrum jest dotknięcie bezmiaru miłości Boga i odkrycie nowej jakości bycia przyjętego w Nim, co wzmacnia zaufanie i staje się źródłem siły oraz motywacji także w trudnych sytuacjach ${ }^{11}$. To doświadczenie ukształtowało charakterystyczną dla Chiary Lubich i Ruchu Focolari wizję życia ludzkiego i świata z jego różnymi obszarami działania ${ }^{12}$.

\subsection{Zmiana perspektywy}

Pisma, w których Chiara Lubich opisuje swoje doświadczenie zanurzenia się w miłości Boga jako źródle zaufania i pewności wiary oraz pełen pasji wysiłek budowania Królestwa Bożego już tu, na tym świecie, zmieniają perspektywę w postrzeganiu życia ludzkiego i społeczeństwa. W głównych tekstach $^{13}$, opisujących to mistyczne doświadczenie Lubich, zauważa się duże znaczenie pola semantycznego słów: „widzieć - postrzegać - patrzeć spoglądać - sposób widzenia - światło": „wydawało się «oczom duszy»"14, „miałam wrażenie, że widziałam” "15; Bóg „wymaga od nas, abyśmy patrzyli na wszystkie kwiaty”16; ,patrzeć na wszystkie kwiaty - to mieć spojrzenie

\footnotetext{
11 Por. Lubich, „Il Patto”, 16-18 (ww. 16-30); Lubich, „Zmartwychwstanie”, 241-245.

12 Por. Lubich, „Patrzeć”, 73-75.

13 Por. Lubich, „Pakt”, „Patrzeć na wszystkie kwiaty” oraz „Zmartwychwstanie”.

${ }^{14}$ Lubich, „Il Patto”, 18 (w. 28) [tłum. własne.; w polskim wydaniu brak tego fragmentu].

15 Tamże.

${ }^{16}$ Lubich, „Patrzeć”, 73.
} 
Jezusa" ${ }^{17}$; „On też patrzył na rzesze ludzi”18; ,Jezus patrzył na taki świat, jaki widzę i ja, ale On nie wątpił”'19; „,Mój wzrok nie jest już zgaszony. Przez źrenicę - próżnię dla duszy, próżnię, przez którą przenika całe Światło, które mam w sobie (jeśli pozwalam Bogu żyć we mnie) - patrzę na świat i na rzeczy. Ale patrzę już nie ja, lecz patrzy we mnie Chrystus” ${ }^{20}$. „Widzę ludzkość oczami Boga"21, a także i w bliźnim jest „,spojrzenie Boga na ludzkość”22.

Kluczowym słowem tych tekstów, powiązanym z perspektywą pola semantycznego: ,postrzegać - sposób patrzenia”, jest ,światło”. Lubich opisuje, że dzięki temu mistycznemu doświadczeniu rzeczywistość relacji zarówno międzyosobowych, jak i struktur społecznych ukazała się jej w absolutnie nowym świetle, to znaczy jakby z punktu widzenia Boga w Trójcy Jedynego. A dla wyrażenia tej rzeczywistości zastosowała pojęcie związane z percepcją: światło, które rozświetla relacje międzyosobowe i społeczne.

Lubich mówi, że „Bóg mógł ją oświecić”, co więcej, że mógł „oświecić Duszę" ${ }^{23}$, by rozświetlić ciemności i ukazało się „całe Światło"24. Opisuje, jak wielu ludzi „pozostawało ze zgaszonym wzrokiem”, ponieważ „w ich duszy panowała ciemność”25. I wyjaśnia: „Staję się całkowicie jedno z Trójcą Świętą, która przebywa w mojej duszy, oświecając ją wiecznym Światłem i wypełniając całym Niebem zamieszkałym przez Świętych [...], którzy [...] mogą znaleźć się wszyscy razem w moim małym sercu, zjednoczeni z Trójcą Świętą w miłości”26. Lubich kontynuuje (jak już było cytowane wyżej): „mój wzrok nie jest już zgaszony [...] ponieważ patrzę na świat $[\ldots]$ przez źrenicę - próżnię dla duszy, próżnię, przez którą przenika całe Światło"27.

\footnotetext{
17 Tamże, 75.

18 Lubich, „Zmartwychwstanie”, 251.

19 Tamże, 252.

20 Tamże.

21 Tamże, 253.

22 Tamże.

${ }^{23}$ Lubich, „Il patto”, 20 (ww. 35n).

${ }^{24}$ Lubich, „Patrzeć”, 75.

${ }^{25}$ Lubich, „Zmartwychwstanie”, 251.

26 Tamże, 252.
}

27 Tamże. W obrazie „źrenicy” Lubich mówi o szczególnym świetle, które poprzez Wcielenie Boga w Jezusie, Jego życie i Jego działalność w Palestynie, poprzez Jego cierpienie i śmierć na krzyżu i Jego Zmartwychwstanie oświeca ludzkie życie: uwalnia ludzką rzeczywistość od więzów śmierci poprzez Mękę Jezusa Chrystusa, aż do opuszczenia na krzyżu i Jego wstąpienie do piekieł w perspektywie Odkupienia i pojednania wszystkiego z Bogiem. 
Autorka opisuje efekt przemiany perspektywy: przejście od ludzkiego postrzegania świata do postrzegania ludzkich relacji, interakcji i struktur społecznych w taki sposób, w jaki widzi je Bóg w Trójcy Jedyny: „Widzę i odkrywam w drugich to samo Światło, które jest we mnie", pozwalając „Bogu żyć we mnie” i umożliwiając Mu ,miłowanie Jego samego w braciach [...]; wówczas «wiele oczu zajaśnieje Jego Światłem»" ${ }^{28}$, by „przelewać je na innych" 29 . Jeśli ludzie będą zmieniać perspektywę, to „wtedy wszystko radykalnie się zmienia: polityka i sztuka, szkoła i życie religijne, życie prywatne i rozrywka. Wszystko"30.

Perspektywa Boga Trójcy, która jest częścią historii objawienia się Boga w tradycji biblijno-chrześcijańskiej - a w którą wpisuje się mistyczne doświadczenie Chiary Lubich - jest charakterystyczną cechą analizowanych tekstów. Jest to coś całkowicie innego niż pragmatyczno-powierzchowny sposób postrzegania relacji w naszym życiu. Na sytuacje pedagogiczne spogląda się raczej z metapoziomu, co umożliwia ocenę okoliczności zachowań relacyjnych w optyce relacyjności Boga Trójjedynego. Można by powtórzyć za Paulem Ricoeurem, że taka zmiana perspektywy z jednej strony prowadzi do hermeneutycznego przeniesienia trynitarnej relacyjności Boga na zjawiska społeczne, z drugiej zaś strony umożliwia głęboką interpretację sytuacji społecznych i pedagogicznych ${ }^{31} \mathrm{~W}$ analogii do relacyjnego modelu trynitarnej formy życia Boga.

\subsection{Relacje międzyludzkie w odniesieniu do relacyjnego życia Boga}

Inna cecha charakterystyczna trzech głównych tekstów dotyczy opisanego wyżej rozumienia ludzkiej egzystencji w analogii do relacyjnej istoty Boga Trójjedynego. Dowodzi tego opis człowieka jako „obrazu Boga” (Rdz 1,26; 5,1; 9,6; Ps 8,5-7), który w teologii biblijno-chrześcijańskiej uważany jest za rozstrzygające wyjaśnienie prawdy o człowieku ${ }^{32}$. Typowo chrześcijańska perspektywa wyraźnie pokazuje, że „byt na obraz Boga trzeba postrzegać

\footnotetext{
${ }^{28}$ Lubich, „Zmartwychwstanie”, 254.

29 Tamże.

30 Tamże.

31 Por. Paul Ricoeur, Verstehende Soziologie. Grundzüge und Entwicklungstendenzen (München: Nymphenburger Verlagshaus, 1972), 292.

32 Por. Wilfried Härle, Dogmatik (Berlin: Walter de Gruyter, 2012), 444.
} 
przez analogię do trynitarnego bytu Boga"33. Imago Dei rozumie się jako imago trinitatis ${ }^{34}$. Podobieństwo człowieka do Boga Trójjedynego z pewnością nie opiera się na cechach charakterystycznych samego człowieka, lecz na fundamencie miłosnej więzi Boga z człowiekiem: „Bóg Trójca stworzył człowieka jako swego interlokutora i przeznaczył go, by istniał przez analogię do Niego. Dlatego człowiek jest obrazem Boga Trójjedynego"35.

Chiara Lubich w opisie swego mistycznego doświadczenia ukazuje koncepcję człowieka, rzeczywistość relacyjną i struktury społeczne w analogii do Boga: „Byt-w-relacji-do siebie” i „,wejść-w-relację-ze-światem”.

W pierwszym z badanych tekstów Lubich pisze, że - zafascynowana miłością i przyjęciem Boga - stojąc u boku Jezusa i wraz z Nim jako swoim bratem, może świadomie nazywać Boga „Ojcem”36.

W drugim tekście stwierdza: „Bóg, który jest we mnie, który ukształtował moją duszę, który w niej zamieszkuje jako Trójca Święta, jest także w sercach braci [...]. I jak kocham Go we mnie, zanurzając się w Nim, kiedy jestem sama, tak kocham Go w bracie, kiedy brat jest przy mnie" ${ }^{37}$. To jest właśnie

łączność między Bogiem we mnie a Bogiem w bracie. I jeśli te dwa Nieba się spotkają, jest tam jedyna Trójca, gdzie ci dwaj są jak Ojciec i Syn, a pomiędzy nimi jest Duch Święty. Trzeba być zawsze skupionym, także w obecności brata [...] przyjmując go do swojego Nieba i zanurzając się w jego Niebie. A ponieważ ta Trójca zamieszkuje w człowieku, jest tam Jezus - Bóg-Człowiek. I wtedy między dwoma jest jedność. Jest się jednym, ale nie jest się samemu. W tym jest cud Trójcy Świętej i piękno Boga [...] który jest Miłością ${ }^{38}$.

W trzecim tekście Lubich w podobny sposób mówi o modlitwie Jezusa: „modląc się w nocy, patrzył w Niebo nad Sobą i w Niebo, które było w Nim, gdzie żyła Trójca Święta"39. Tak samo autorka opisuje swój wysiłek:

33 Liedke, „Inklusion”, 34.

34 Tamże.

35 Tamże. We współczesnej antropologii chrześcijańskiej, szczególnie Dietricha Bonhoeffera, Karla Bartha, Leonarda Boffa, Klausa Hemmerlego, Gisberta Greshakego, Jürgena Moltmanna i Christophera Schwöbela, mówi się o trynitarnym rozumieniu bytu człowieka na obraz Boga.

36 Por. Lubich, „Il Patto”, 18 (ww. 26n).

37 Por. Lubich, „Patrzeć”, 74.

38 Tamże.

${ }^{39}$ Lubich, „Zmartwychwstanie”, 252. 
Staję się całkowicie jedno z Trójcą Świętą, która przebywa w mojej duszy, oświecając ją wiecznym Światłem i wypełniając całym Niebem i w ten sposób [...] wchodzę w kontakt z Ogniem, który przenikając całe moje człowieczeństwo dane mi przez Boga, czyni mnie drugim Chrystusem, drugim Bogiem-Człowiekiem przez uczestnictwo. Moje człowieczeństwo stapia się z tym, co Boskie, a mój wzrok nie jest już zgaszony [...] lecz przenika całe Światło, które mam w sobie (jeśli pozwalam Bogu żyć we mnie) ${ }^{40}$.

I dlatego, pisze Lubich:

widzę i odkrywam w drugich to samo Światło, które jest we mnie, moją prawdziwą Rzeczywistość, moje prawdziwe ,ja" w drugich [...]. W ten sposób [...] buduję żywą i kompletną komórkę Mistycznego Ciała Chrystusa, komórkę żywą, focolare (ognisko) Boże, które ma do przekazywania Ogień, a wraz z nim Światło. To Bóg czyni z dwóch jedno, zajmując pozycję Trzeciego, jako ich wzajemne odniesienie - Jezus pomiędzy nami. [...] Wtedy rzeczywiście cały Chrystus zaczyna na nowo żyć i w obu, i w każdym, i między nami: On, Bóg-Człowiek, z najrozmaitszymi przejawami tego, co ludzkie, przenikniętymi tym, co Boże [...]. Jeśli pozwalamy żyć Bogu w nas ${ }^{41}$.

W ujęciu Lubich relacyjne życie Boga Trójjedynego można przenieść na relacje międzyosobowe we wspólnocie chrześcijańskiej. Wyraża to poprzez (eklezjologiczne) odniesienia do Kościoła jako „Ciała Chrystusa z wieloma członkami”, wydobywając chrystologiczną przemianę (trasformazione cristologica) koncepcji Boga, który przez wieki towarzyszy swojemu ludowi w Jezusie, zawsze tam, gdzie ludzie żyją razem, jeden dla drugiego i dla wszystkich w jego duchu (por. Mt 18,20).

Według koncepcji antropologii teologicznej ludzie są wezwani do odtwarzania w relacjach między sobą oraz w strukturach społecznych bogactwa relacji trynitarnych Boga. Interpretacja mistycznego doświadczenia Chiary Lubich, w odniesieniu do relacyjnej rzeczywistości Boga Trójjedynego, niesie ze sobą wyraźny potencjał inspiracji i motywacji dla praktyki pedagogicznej w zakresie relacji wychowawczej. Ten sposób widzenia relacji wychowawczych pozwala zobaczyć to, co w przyszłości Bóg może uczynić możliwym, a jednocześnie już teraz przyczynia się do jej przemieniania. $Z$ analizy i inter-

\footnotetext{
40 Tamże.

${ }^{41}$ Por. tamże, 253.
} 
pretacji relacji wychowawczych, które wzorują się na dynamice i trynitarnym sposobie życia Boga, można wyprowadzić kryteria do oceny pedagogicznych przestrzeni relacyjnych oraz do stymulacji przemiany działań edukacyjnych tak, aby coraz bardziej odpowiadały trynitarnemu modelowi różnorodności w komunii.

\subsection{Dynamika inspiracji, motywacji i zaangażowania}

Analizując na potrzeby tego studium trzy wybrane teksty o mistycznym doświadczeniu Chiary Lubich, podkreśla się charakterystyczną dynamikę jej mistyki. Są to:

1. Poruszenie wewnętrzne $\mathrm{z}$ nastawieniem na potwierdzenie, że doświadczenie bycia przyjętym w miłości przez Boga jest prawdziwe ${ }^{42}$.

2. Pierwsze poruszenie ku zewnątrz: (a) aby zrozumieć ludzką rzeczywistość relacyjną z perspektywy Boga Trójjedynego; (b) by zinterpretować ludzką rzeczywistość relacyjną w analogii do trynitarnego sposobu życia Boga.

3. Drugie poruszenie ku zewnątrz: (a) w celu interakcji z innymi osobami; (b) w celu interpretacji tej interakcji w świetle trynitarnej relacyjności Boga.

4. Następne poruszenie ku zewnątrz na rzecz nowej konfiguracji, nie tylko samych interakcji interpersonalnych, ale także struktur społecznych odpowiadających relacyjnej formie trynitarnego życia Boga.

5. Ostateczne wejście relacyjnej rzeczywistości ludzi i struktur społecznych, rozumianych jako imago trinitatis (na obraz relacji Boga Trójcy), w etap spełnienia się Królestwa Bożego, które będzie dokonane przez Boga w czasach ostatecznych.

Przenosząc te pięć dynamicznych kroków mistycznego doświadczenia Lubich na doświadczenia osób, które pracują w środowisku pedagogicznym, można wywnioskować, że:

1. Wychowawcy potrzebują momentów wewnętrznego skupienia, w znaczeniu już wspomnianym, tj. momentów, w których spotykają się z samymi sobą. Doświadczenia tego typu ujawniają ważne źródła siły, są także potrzebne w trudnych chwilach pracy zawodo-

42 To wewnętrzne skupienie się Chiary Lubich i Focolari sięga aż po zamieszkiwanie (zadomowienie się) w rzeczywistości Boga Trójcy i nieustanne dążenie do postrzegania ludzi oraz świata z perspektywy Boga. 
wej oraz wzmacniają zaufanie i wiarę, że życie i zaangażowanie pedagogiczne mogą przynieść sukces. Te doświadczenia wzmacniają też zaufanie, otwarcie się, zaangażowanie w relacje pedagogiczne i wypełnianie powierzonych obowiązków, a także zdolność do zostawienia wolności odejścia ludziom młodym lub dorosłym, którzy posiedli niezbędne kompetencje merytoryczne, osobiste i społeczne do samodzielnego prowadzenia swojego życia. Wychowawcy, którzy mają dostęp do bogactw duchowych w wypełnianiu obowiązków zawodowych i przezwyciężaniu wszelkich trudności, mogą korzystać także ze strategii o takiej naturze. Obok wparcia nadprzyrodzonego bardzo ważne wydaje się również szerokie wsparcie społeczne. Osoby wierzące mogą doświadczyć, że modlitwa, ich zaufanie Bogu oraz siła wiary mogą przyczyniać się do wzmocnienia pewności siebie, sił wewnętrznych i wytrzymałości. Ponadto należy także brać pod uwagę znaczenie wsparcia społecznego ze strony kolegów, którzy czerpią z podobnych źródeł motywacji i wsparcia.

2. Wychowawcy potrzebują także momentów, w których mogą nabrać dystansu koniecznego do autorefleksji. Postrzeganie z perspektywy Boga rzeczywistości relacyjnej na polu pedagogiki oraz namysł nad aktualną sytuacją $\mathrm{w}$ praktyce i układem relacji mogą być narzędziem krytycznej refleksji nad praktyką pedagogiczną na podstawie modelu trynitarnego życia Boga.

3. Wychodząc od systematycznej refleksji nad własną praktyką zawodową oraz sięgając do zasobów inspiracji i motywacji, wychowawcy mogą nie tylko zrozumieć i interpretować własne interakcje pedagogiczne w perspektywie trynitarnej rzeczywistości Boga, ale także zmieniać i ustawiać je według tego modelu.

4. Jeśli coraz więcej pedagogów czerpie siły z dobrych źródeł inspiracji i fachowo zastanawia się nad swoją praktyką edukacyjną, to we współpracy z innymi strategicznie wybranymi partnerami mogą oni krytycznie i konstruktywnie przekształcać szkolne i edukacyjne struktury społeczeństwa, tak aby stopniowo i w pewien sposób odzwierciedlały one relacyjne życie Boga Trójcy.

5. Wychowawców, którzy znajdują swoje inspiracje i motywacje w tradycji biblijno-chrześcijańskiej, wiara może uwolnić od wrażenia, że muszą wypełnić wszystkie swoje obowiązki pedagogiczne sami, własnymi siłami, podczas gdy to Bóg wspomaga ich zaangażowanie i doprowadza do jego realizacji. 
Możemy stwierdzić, że postrzeganie i interpretacja różnych sytuacji edukacyjnych z punktu widzenia modelu życia Boga Trójcy uwalnia wielki potencjał, siłę i wizję (z „wysoka”, jak powiedziałaby Chiara Lubich) oraz wyraźne ukierunkowanie, mobilizując zaufanie i wolność. Taka przemiana perspektywy może generować nowe kategorie i kryteria refleksji, weryfikacji i, jeśli to konieczne, transformacji przestrzeni relacyjnych, a także różnych form praktyki pedagogicznej dotyczącej wychowania do „,różnorodności w komunii” i ,jedności w różnorodności”, w bezpośrednim związku z modelem relacyjnego życia Boga Trójcy.

\section{Wnioski dotyczące zalożeń pedagogii inspirowanej duchowością jedności}

W pedagogii relacji, która inspiruje się duchowością Ruchu Focolari, uwzględnia się dwa podstawowe aspekty antropologiczne. Po pierwsze, jak w każdym dyskursie pedagogicznym, zwraca się uwagę na określoną koncepcję dziecka, leżącą u podstaw danej teorii wspierającej praktykę edukacyjną.

Czy dziecko widziane jest jako byt bezbronny, zależny, potrzebujący przewodnictwa, który tylko poprzez edukację może stać się kompletnym człowiekiem? Czy też widziane jest jako zasadniczo autonomiczny, wolny podmiot, potencjalnie kompetentny, ale także potrzebujący pomocy i towarzyszenia, by być aktywnym twórcą swego rozwoju? W zależności od odpowiedzi na tak konkretne pytanie o koncepcję dziecka, człowieka [...] wychowanie będzie miało całkowicie różną teorię i praktykę ${ }^{43}$.

Kiedy w praktyce edukacyjnej albo w dyskursie naukowym mówi się o wychowaniu, trzeba przede wszystkim wyjaśnić, którą koncepcję - z tych dwóch przeciwstawnych - się przyjmuje. Następnie należy krytycznie ocenić te wybrane założenia odnośnie do człowieka.

Po drugie, w pedagogii relacji uwzględnia się duchowy wymiar człowieka w świetle antropologii teologicznej ${ }^{44}$; wymaga to jednak czytelnego wyjaśnienia poprzez dialog z zainteresowanymi tym aspektem. W tekstach

\footnotetext{
${ }^{43}$ Boschki, ,Grundoptionen”, 21.

44 Tamże, 21.
} 
Chiary Lubich o mistycznym doświadczeniu znajdujemy koncepcję człowieka zgodną z antropologią teologiczną, wywodzącą się z tradycji biblijno-chrześcijańskiej. Działanie edukacyjne zainspirowane koncepcją człowieka-relacji, człowieka jako ikony Trójcy Świętej ${ }^{45}$, której modelem jest opisana w badanych tekstach trynitarna dynamika relacyjna, opiera się przede wszystkim na wewnętrznej sile wychowawcy, wyznaczającej ich charakter. „Ten, kto postrzega osobę $\mathrm{w}$ jej bezpośrednim odniesieniu do Boga, ma świadomość, że jest ona zdolna wejść w relację z Bogiem, nawet jeśli - jako dziecko, młody lub dorosły - nie otrzymała formacji religijnej, albo z jakiegokolwiek powodu nie odnalazła swojej relacji z Bogiem" "46. W perspektywie wynikającej z antropologii teologicznej oczywista jest zdolność człowieka do otwartości na Boga i realnej możliwości nawiązania z Nim relacji ${ }^{47}$.

$\mathrm{W}$ dialogu $\mathrm{z}$ wychowawcami zainteresowanymi powyższym może być ważne wyjaśnienie, że dla tego, kto kieruje się zasadami duchowości jedności, koncepcja człowieka odnajduje swój fundament w antropologii, u podstaw której leży wizja trynitarnej relacji Boga. W tymże dialogu niezbędne jest również wyjaśnienie, że ten sposób myślenia i działania pedagogicznego niesie ze sobą także określone implikacje etyczne ${ }^{48}$. Ponadto po dookreśleniu źródła takich inspiracji i motywacji - tzn. antropologii teologiczno-chrześcijańskiej, w którą wpisuje się mistyczne doświadczenie Chiary Lubich - łatwiej będzie ukazać związek tego doświadczenia z naukową refleksją w zakresie nauk o edukacji oraz jego powiązanie z konkretnymi źródłami chrześcijańskimi i refleksją teologiczną.

Dzięki lekturze i analizie tekstów Lubich, jako źródeł inspiracji, stanie się możliwe zrozumienie wielu sytuacji praktyki pedagogicznej rozpatrywanych na różnych poziomach interpretacji: (a) interpretacji sytuacji pedagogicznych w świetle antropologii pedagogicznej, (b1) interpretacji sytuacji pedagogicznych w świetle antropologii teologicznej, (b2) interpretacji sytuacji pedagogicznych w świetle koncepcji człowieka i relacji interpersonalnych jako obrazu trynitarnego życia Boga, (b3) interpretacji sytuacji pedagogicznych w świetle mistycznego doświadczenia Chiary Lubich i (powiązanej z nim) antropologii opartej na fundamencie teologii trynitarnej.

45 Por. Chiara Lubich, „Charyzmat jedności i pedagogika”, w: Charyzmat jedności, red. Michel Vandeleene (Kraków: Fundacja Mariapoli, Wydawnictwo M, 2007), 319.

46 Por. Boschki, „Grundoptionen”, 21.

${ }^{47}$ Por. tamże.

${ }^{48}$ Hans Schalk e il gruppo di studio Pedagogia in Relazioni, „Pädagogische Beziehungen”, Charismen 2/24 (2012): 8. 
Poza tym w dialogu pedagogów inspirujących się duchowością jedności z ekspertami nauk o edukacji, reprezentującymi inne orientacje, kluczowe jest poszukiwanie nie tylko zbieżności ${ }^{49}$, ale także poszanowanie wartości i metod tychże orientacji, gdyż mogą one zawierać istotne elementy tradycji biblijno-chrześcijańskiej, pominięte lub przeoczone przez pedagogów Ruchu Focolari, a mogące przyczynić się do rozwoju ich koncepcji i projektów. Jednocześnie ocena i analiza innych orientacji pedagogicznych zachęcają do krytycznego przebadania tych podejść w świetle kryteriów tradycji biblijno-chrześcijańskiej, a zawłaszcza w modelu trynitarnej relacji Boga.

$\mathrm{W}$ podsumowaniu tego artykułu chciałabym raz jeszcze zwrócić uwagę na to, co wynika $z$ analiz i interpretacji trzech wybranych tekstów o mistycznym doświadczeniu Lubich. Doprowadziły one do wypracowania niektórych wytycznych dla pedagogii relacji, która inspiruje się tymże doświadczeniem, a przez to odnosi się do podstaw duchowości jedności. $Z$ jednej strony w odniesieniu do celów pedagogii relacji - w szczególności pedagogii „różnorodności w jedności” i ,jedności w różnorodności”, do której mogą dążyć ci wszyscy, którzy pragną być dobrymi wychowawcami, nauczycielami i studentami; z drugiej zaś strony w odniesieniu do głębokich inspiracji i silnych motywacji, by dążyć do tych celów.

W działaniach edukacyjnych nie zawsze łatwo jest realizować cele pedagogii relacji, ,różnorodności w jedności” i ,jedności w różnorodności”. Teksty o mistycznym doświadczeniu Lubich - być może nie jako jedyne zawierają pewien potencjał inspiracji i motywacji typowych dla pedagogii focolare. Ponieważ cele są wzniosłe, a przez to trudne do osiągnięcia, wymagają przestrzeni relacyjnych, gdzie możliwe byłoby dzielenie się nie tylko trudnościami i upadkami, ale także doświadczeniami i pozytywnymi rezultatami, i gdzie zawsze na nowo można by korzystać z niewyczerpalnych źródeł inspiracji i silnych motywacji, jakie daje duchowość jedności. Takie przestrzenie relacyjne oczekiwałyby w konsekwencji ustalonego ukierunkowania ku dzieleniu się i wzajemnemu obdarowaniu - w analogii do dynamiki życia trynitarnego, pozwalającej iść naprzód nawet wtedy, gdy zrodzą się trudności i nieuniknione przeciwności.

Pedagogiczne przestrzenie relacyjne mogłyby się w swojej dynamice rozprzestrzenić poprzez współpracę ze strategicznymi partnerami, którzy będą angażować się na rzecz zbieżnych ideałów (np.: działań i wychowania dla pokoju). Mogłyby także krok po kroku przemieniać struktury edukacji

49 Por. Mette, Steinkamp, Sozialwissenschaften, 164-176, zwłaszcza 168n. 
i nauczania publicznego w duchu pedagogii „różnorodności w jedności” i ,komunii w różnorodności”.

\author{
Ttumaczenie: Stanistaw Grochmal, \\ Mariola T. Kozubek, Małgorzata Radomska
}

\title{
Bibliografia
}

Boschki, Reinhold i inni. „Grundoptionen der Religionspädagogik”. W: Religionspädagogische Grundoptionen, red. Reinhold Boschki, 19-43. Freiburg: Verlag Herder, 2008.

Härle, Wilfried. Dogmatik. Berlin: Walter de Gruyter, 2012.

Klafki, Wolfgang. „Zur Unterrichtsplanung im Sinne kritisch-konstruktiver Didaktik". W: Neue Studien zur Bildungstheorie und Didaktik. Zeitgemäße Allgemeinbildung und kritisch-konstruktive Didaktik, red. Wolfgang Klafki, 251-284. Weinheim und Basel: Beltz Verlag, 1996.

Kron, Friedrich W. Grundwissen Didaktik. München: Reinhardt, 2000.

Kron, Friedrich W. Wissenschaftstheorie für Pädagogen. München: Reinhardt, 1999. Liedke, Ulf. „Inklusion in theologischer Perspektive”. W: Handbuch Inklusion in der Kirchengemeinde, red. Kunz Ralph, 31-52. Göttingen: Vandenhoeck\&Ruprecht 2013.

Lubich, Chiara. „Il Patto”. W: Il Patto del '49 nell'esperienza di Chiara Lubich. Percorsi interdisciplinari, red. Vera Araújo, Maria Caterina Atzori i in., 16-18. Roma: Città Nuova, 2012.

Lubich, Chiara. „Charyzmat jedności i pedagogika”. W: Chiara Lubich, Charyzmat jedności, red. Michel Vandeleene, 313-320. Kraków: Fundacja Mariapoli, Wydawnictwo M, 2007.

Lubich, Chiara. „Patrząc na wszystkie kwiaty”. W: Chiara Lubich, Charyzmat jedności, red. Michel Vandeleene, 60-62. Kraków: Fundacja Mariapoli, Wydawnictwo M, 2007.

Lubich, Chiara. ,Zmartwychwstanie Rzymu”. W: Chiara Lubich, Charyzmat jedno$s c i$, red. Michel Vandeleene, 241-245. Kraków: Fundacja Mariapoli, Wydawnictwo M, 2007.

Lubich, Chiara. Duchowość jedności nowa droga. Kraków: Fundacja Mariapoli, 2004.

Mette, Norbert, Hermann Steinkamp. Sozialwissenschaften und Praktische Theologie. Düsseldorf: Patmos, 1983. 
Ricoeur, Paul. Verstehende Soziologie. Grundzüge und Entwicklungstendenzen. München: Nymphenburger Verlagshaus, 1972.

Schalk, Hans oraz grupa badawcza Pedagogika w Relacjach. „Pädagogische Beziehungen". Charismen 24 (2/2012) 2-9.

Stogianidis, Athanasios. Leben und Denken: Bildungstheorien zwischen Theosis und Rechtfertigung. Eine Untersuchung zum Verhältnis von Evangelischer und Orthodoxer Religionspädagogik. Münster: Lit, 2003. 
